\title{
Analisis Framing Pemberitaan Media Online Tribunjogja.com dan Detik.com (Kasus Suap Taufik Hidayat dan Eks Menpora)
}

\author{
Eka Yudha P. ${ }^{1}$, Abraham Eleazar A. P. ${ }^{2}$, Retno Wahyu Larasati ${ }^{3}$. \\ Ilmu Komunikasi, UPN Veteran Jawa Timur \\ ekayudhap24@gmail.com, abrahamputra01@gmail.com, \\ retno.wahyu1@gmail.com
}

Received: November 10, 2020; Revised: January 13, 2021; Accepted: January 23, 2021

\begin{abstract}
Abstrak
Bulu tangkis merupakan salah satu olahraga yang digemari oleh masyarakat Indonesia. Salah satu pebulu tangkis hebat yang dimiliki Indonesia adalah Taufik Hidayat. Kehidupan Taufik Hidayat tidak lepas dari banyaknya kontroversi dimana salah satu kasus kontroversi terbarunya adalah pengakuan Taufik Hidayat sebagai perantara suap dana Hibah Komite Olahraga Nasional Indonesia (KONI) kasus korupsi Menpora Imam Nahrawi di Pengadilan Tipikor Jakarta. Terkait perkembangan kasus ini, media dituntut untuk menyampaikan informasi terkini dan cepat kepada masyarakat, yaitu dengan perantara media online. Media online merupakan media yang sangat gencar dalam memberitakan kasus ini dengan meng-update berita terkini secepat mungkin di setiap harinya. Salah satu media online yang selalu memberitakan kasus ini secara runtut setiap harinya yaitu TribunJogja.com dan Detik.com. Penelitian ini merupakan penelitian kualitatif dengan pendekatan analisis framing model Zhongdang Pan dan Koscki berupa sintaksis, skrip, tematik dan retoris. Konsep tersebut didasarkan pada teori Peter L. Berger untuk membedah suatu realitas berita, yaitu Teori Realitas Konstruksi Sosial. Hasil penelitian menunjukkan media online Tribunjogja.com memiliki isi berita yang tidak hanya mengedepankan pendapat salah satu pihak. Hal ini membuat berita yang ditulis oleh Tribunjogja.com berita yang berimbang tidak memihak manapun. Sedangkan media online Detik.com memiliki isi berita yang lebih mengedepankan pendapat / pengakuan dari Taufik Hidayat saja. Hal ini berarti media online Detik.com terlihat memihak satu pihak dan tidak berimbang, yang seharusnya suatu berita memiliki isi yang berimbang atau netral tanpa memihak siapapun.
\end{abstract}

Kata Kunci : Framing, Media Online, Taufik Hidayat, Korupsi.

\begin{abstract}
Badminton is one of the sports favored by the Indonesian people. One of Indonesia's great badminton players is Taufik Hidayat. In Taufik Hidayat's own life, there are many controversies. One of the most recent controversial cases is the admission of Taufik Hidayat as an intermediary for bribes of grants from the Indonesian National Sports Committee (KONI) for the corruption case of Menpora Imam Nahrawi at the Corruption Court in Jakarta. Regarding the development of this case, the media are required to convey current and fast information to the public, namely by means of online media. Online media is the kind of media which is very active in reporting on this case, they update the latest news as quickly as possible every day. One of the online media that always reports this case coherently every day is TribunJogja.com and Detik.com. This
\end{abstract}


research is the kind of qualitative research with a framing analysis approach Zhongdang Pan and Koscki's models are syntactic, script, thematic and rhetorical. The concept is based on the theory of Peter L. Berger to dissect a news reality, namely the Social Construction Reality Theory. The results showed that the online media Tribunjogja.com had news content that did not only promote the opinion of one party. This makes the news written by Tribunjogja.com a balanced news that does not take sides. Meanwhile, the online media, Detik.com, has news content that emphasizes Taufik Hidayat's opinion I confession. This means that the online media Detik.com appears to be one-sided and unbalanced, which should be news that has balanced or neutral content without taking sides.

Keywords : Framing, Online Media, Taufik Hidayat, Corruption.

\section{Pendahuluan}

Dunia olahraga kini semakin berkembang di Indonesia. Bulu tangkis merupakan salah satu olahraga yang digemari oleh masyarakat Indonesia. Organisasi yang menaungi bulu tangkis di Indonesia adalah PBSI (Persatuan Bulu tangkis Seluruh Indonesia). Olahraga ini menjadi andalan di berbagai ajang lomba bergengsi seperti, Asian Games, Sea Games hingga Olimpiade bahkan di ajang yang terakhir ini lumbung emas Indonesia sangat mengandalkan dari cabang bulu tangkis ini. Terlihat dari beberapa perolehan prestasi medali emas di ajang perlombaan Sea Games sejak tahun 1977-2017 (Aditama, 2019).

Banyak prestasi yang telah diraih oleh Taufik Hidayat sebagai salah satu putra terbaik Indonesia dimana ia berhasil memperoleh gelar prestisius di dunia bulu tangkis. Beberapa perolehan Taufik Hidayat adalah Gelar Juara Dunia, Piala Sudirman, Piala Thomas, dan medali emas Olimpiade di Athena tahun 2004 silam. Taufik Hidayat juga memperoleh peringkat 1 dunia termuda, pemegang rekor backhand smash tercepat dan meraih 6 gelar juara Indonesia Open (https://m.merdeka.com/taufikhidayat/profill, diakses 26 September 2020)

Taufik Hidayat telah pensiun dari dunia bulu tangkis sejak pertengahan 2013 lalu. Kehidupan Taufik Hidayat sendiri tidak lepas dari banyaknya kontroversi baik saat masih menjadi atlet maupun sudah pensiun kini (Rahmat, 2015). Salah satu kasus kontroversinya terbaru adalah pengakuan Taufik Hidayat sebagai perantara suap kasus korupsi Menpora Imam Nahrawi. Pengakuan yang disampaikan oleh Taufik Hidayat ini pada saat menjadi saksi dalam sidang lanjutan kasus suap dana Hibah Komite Olahraga Nasional Indonesia (KONI) dengan terdakwa Imam Nahrawi di Pengadilan Tipikor Jakarta, Jakarta Pusat.

Pengakuan yang disampaikan oleh Taufik Hidayat semakin menarik perhatian publik saat Taufik Hidayat diundang menjadi bintang tamu dalam podcast channel milik Deddy Corbuzier. Dalam kesempatan tersebut Taufik Hidayat blak-blakan soal korupsi yang terjadi di Kementerian Pemuda dan 
Olahraga. Selain pengakuan menjadi kurir suap korupsi, Taufik juga mengatakan bahwa banyak "tikus" di Kemenpora yang membuat korupsi di Kementerian tersebut sudah mendarah daging dan disitu Taufik juga menyinggung bahwa olahraga tidak akan maju jika tetap dibawa dalam politik.

Media massa menjalankan perannya sebagai penyampai dan penyalur informasi bagi khalayak umum (publik) dengan sikap profesional. Profesionalisme media dapat dilihat dari perpaduan ketrampilan memilih peristiwa yang memenuhi kriteria nilai berita sekaligus menyeimbangkan kepentingan berbagai pihak dalam sebuah peristiwa (Abrar dalam Heri, 2020).

Dari peristiwa pengakuan Taufik Hidayat sebagai saksi di pengadilan Tipikor Jakarta serta pengakuan yang disampaikan didalam podcast channel milik Deddy Corbuzier tersebut menarik atensi beberapa media online sebagai bahan liputan untuk portal berita media online. Disini terdapat 2 media online yang melakukan pemberitaan terkait peristiwa tersebut yang memiliki perbedaan sudut pandang dalam membuat berita yaitu Detik.com yang pemberitaan nya mengangkat semua pengakuan yang dilakukan oleh Taufik Hidayat terkait banyaknya 'tikus' di Kemenpora, sedangkan

\section{Kerangka Teori}

\section{Media Online}

TribunJogja.com lebih condong memberitakan respon dari kemenpora yang diwakili langsung oleh Menpora dalam menjawab pengakuan yang dilakukan oleh Taufik Hidayat.

Media tidak bisa dikatakan bebas dan independen, karena media memiliki kaitan dengan realitas sosial. Menurut pandangan konstruksionis, dalam menampilkan, media massa maupun media online tertentu mempunyai ideologi tersendiri dalam pembingkaian beritanya. Media mengarahkan perhatian khalayaknya mengenai isu tertentu yang kemudian khalayak menerimanya sesuai dengan persepsi mereka masing-masing. Media dianggap sebagai pembangun konstruk sosial yang mendefiniskan realitas, itulah yang menjadikan media sebagai saluran yang bertanggung jawab. (Eriyanto dalam Heri 2020).

Banyaknya media yang memberitakan kasus ini maka peneliti akan mengambil dua berita yang berbeda dari dua media yang juga berbeda yaitu Detik.com pada tanggal 11 Mei 2020 dan Tribunjogja.com pada tanggal 15 Mei 2020. Berdasar latar belakang yang telah dijabakan, penelitian ini bertujuan untuk mendeskripsikan bingkai pemberitaan TribunJogja.com dan Detik.com terkait kasus suap Taufik Hidayat dan Eks Menpora.

Media terpenting dan memiliki jaringan paling luas saat ini adalah internet, yang menghubungkan komputer-komputer pribadi yang paling sederhana hingga 
komputer super yang paling canggih, inilah struktur jaringan komputer yang saling berhubungan. Dewasa ini, muncul banyak perangkat yang memungkinkan kita untuk mengakses internet. Mulai dari PC, tablet, hingga telepon pintar (smartphone) yang kini tersedia dalam beragam variasi. Jaringan internet adalah media yang paling cepat berinovasi ke segala lini dan paling adaptif dengan kebutuhan masyarakat sehingga hampir semua media dan kebutuhan masyarakat dapat dikoneksikan ke dalam jaringan-jaringan internet ini. Dalam perkembangan yang terus menerus sering timbul adanya pro dan kontra terhadap kehadiran teknologi ini. Teknologi sendiri memiliki pengaruh negatif maupun positif dalam setiap kehidupan manusia tergantung dari cara penggunaan teknologi tersebut. Hal ini berarti setiap produk teknologi memiliki fungsi baik dari segi positif dan negatif yang berfungsi melekat pada waktu yang bersamaan (Yudiningrum, 2016). Teknologi informasi diharapkan dapat mendukung pengurangan resiko bencana melalui berbagai berita pada media online melalui jaringan Internet. Mengingat beberapa kelebihan media online yang sangat cepat, dari segi waktu dan dalam menyampaikan beritanya, praktis dan fleksibel, serta dapat diakses dari mana saja dan kapan saja.

Media online adalah tatanan baru yang terus mengalami perkembangan (Pavlik, 2003:45). Media online biasanya berupa website. Dalam penggunaannya, media online sering disertai dengan hypertext. Hypertext yaitu teks online yang dihubungkan ke halaman lain pada sebuah web melalui kode HTML. (Pavlik, 2003:28). Media online merupakan hasil dari kajian teknologi komunikasi yang menawarkan kepada penggunanya sebagai media alat komunikasi interpersonal atau juga disebut media interaktif, yaitu media memungkinkan partisipan ikut aktif baik penerima maupun pengirim. Media online memiliki keunggulan dibanding dengan media cetak, yaitu dapat menampung berita seperti tulisan e-journal, gambar, suara dan video. Berbeda dengan media cetak, yang hanya menampilkan tulisan dan gambar.

Online atau familiar disebut Internet berarti bahwa informasi dapat diakses di mana saja dan kapan saja selama terhubung dengan jaringan Internet. (Aisyah, Pantow, \& Koagouw, 2015). Internet merupakan sumber informasi baru, karena sifatnya yang tak terbatas baik konten maupun ruang yang melekat padanya. Setiap informasi yang ada di media online selalu diperbarui setiap saat, bahkan mampu mendokumentasikan semua informasi yang siap diakses oleh pengunjung media online yang bersangkutan pada waktu kapan pun sepanjang tidak terhalang oleh akses jaringan internet baik yang menggunakan media komunikasi kabel maupun nir kabel seperti sinyal Wi-Fi (Siswanta dalam Puji Lestari 2018).

Banyak masyarakat saaat ini menemukan berita melalui media online, tetapi masih banyaknya media online yang ada dianggap tidak mengedepankan netralitas antara lain ketepatan, kelengkapan, 
keadilan berita dan hanya seakan untuk mengejar kecepatan terbit saja yang tidak memperhatikan kebeneran informasi tersebut. Kadang-kadang hal ini yang menjadi penyebab masalah di dalam masyarakat, karena media online dengan keunggulan penyebaran informasi menjadi lebih cepat daripada media yang lainnya, namun disisi lain kecepatan ini meninggalkan prinsip-prinsip dasar jurnalisme di antaranya ketepatan berita, wartawan kurang mengecek sumber berita yang komprehensif.

\section{Teori Konstruksi Sosial Atas Realita (The Social Construction Of Reality Theory)}

Salah satu teori yang berpengaruh pada sebuah kajian media adalah Teori Peter L. Berger, yaitu tentang Konstruksi Sosial Atas Realitas atau yang disebut dengan Konstruksi Realitas. Media memiliki realitas yang disebut realitas media, media menyusun realitas dari berbagai peristiwa yang terjadi sehingga menjadi cerita atau wacana yang bermakna (Hamad, 2004), dan realitas yang ditampilkan media tidak dipahami sebagai seperangkat fakta, akan tetapi hasil pandangan tertentu tercipta dari hasil pembentukan realitas (Eriyanto, 2002). Melalui sentuhan Hegel, yaitu Tesis, Antitesis dan Sintesis, Berger menemukan konsep untuk menghubungkan konsep yang memiliki makna realitas antara yang subjektif dan objektif itu melalui konsep dialektika, yang dikenal sebagai Eksternalisasi, Objektivasi, dan Internalisasi. Pendekatan konstruksionis memeriksa bagaimana pembentukan pesan dari sisi komunikator dan dalam sisi penerima ia memeriksa bagaimana konstruksi makna individu ketika menerima pesan. Pesan dipandang bukan sebagai mirror of reality yang menampilkan fakta apa adanya. (Eriyanto, 2002).

$\begin{array}{lrr}\text { Menurut } & \text { (Hamad, 2001) } \\ \text { Bahasa bukan hanya } & \text { mampu } \\ \text { mencerminkan realitas } & \text { tetapi } \\ \text { sekaligus menciptakan } & \text { realitas. }\end{array}$
Bahasa merupakan instrumen pokok untuk menceritakan realitas. Maka dari itu sangat penting nya bahasa dalam sebuah komponen pokok berita bahkan dalam cerita maupun ilmu pengetahuan sekalipun. Menurut Heri (2020), setiap teks dan penulisan berita pada dasarnya dihasilkan lewat kesadaran, pengetahuan, prasangka atau pengetahuan tertentu atas suatu peristiwa.

Istilah konstruksi atas realitas sosial menjadi terkenal sejak diperkenalkan oleh Peter L. Berger (1966). Berger \& Luckmann berpandangan bahwa kenyataan atau realitas dibangun secara sosial dalam pengertian individu-individu dalam masyarakat itulah yang membangun masyarakat. Berger memandang manusia sebagai makhluk yang mampu menciptakan kenyataan sosial yang objketif melalui tiga proses yaitu eksternalisasi, objektivasi, dan internalisasi.

1. Eksternalisasi, yaitu usaha pencurahan atau ekspresi diri manusia kedalam dunia, baik dalam kegiatan mental maupun fisik. Proses ini merupakan bentuk ekspresi diri untuk menguatkan eksistensi individu 
dalam masyarakat. Pada tahap ini masyarakat dilihat sebagai produk manusia.

2. Objektifikasi, adalah hasil yang telah dicapai, baik mental maupun fisik dari kegiatan eksternalisasi manusia tersebut. Hasil itu berupa realitas objektif yang bisa jadi akan menghadapi si penghasil itu sendiri sebagai suatu faktisitas yang berada diluar dan berlainan dari manusia yang menghasilkannya (hadir dalam wujud yang nyata). Realitas objektif itu berbeda dengan kenyataan subjketif perorangan. Ia menjadi kenyataan empiris yang bisa dialami oleh setiap orang. Pada tahap ini masyarakat dilihat sebagai realitas yang objektif, atau proses interaksi sosial dalam dunia intersubjektif yang dilembagakan atau mengalami proses institusionalisasi.

3. Internalisasi, lebih merupakan penyerapan kembali dunia objektif ke dalam kesadaran sedemikian rupa sehingga subjektif individu dipengaruhi oleh struktur dunia sosial. Berbagai macam unsur dari dunia yang telah terobjektifikasi tersebut akan ditangkap sebagai gejala realitas diluar kesadarannya, sekaligus sebagai gejala internal bagi kesadaran. Manusia menjadi hasil dari masyarakat dari proses internalisasi.

\section{Analisis Framing}

\begin{tabular}{lr}
\multicolumn{1}{c}{ Dalam } & perspektif \\
komunikasi, analisis & framing \\
digunakan untuk membedah cara-
\end{tabular}

cara atau ideologi media saat mengkonstruksi fakta. Analisis ini mencermati strategi seleksi, penonjolan dan pertautan fakta ke dalam berita agar lebih bermakna, lebih menarik, ataupun lebih diingat, untuk menggiring interpretasi khalayak sesuai perspektifnya. Framing ialah pendekatan untuk mengetahui bagaimana perspektif atau cara pandang yang digunakan oleh wartawan ketika menyeleksi isu dan menulis berita. (Sobur, 2002:162).

Analisis Framing secara sederhana dapat digambarkan sebagai analisis untuk mengetahui bagaimana realitas (peristiwa, aktor, kelompok atau apa saja) dibingkai oleh media. Pembingkaian tersebut tentu saja melalui proses konstruksi. Peristiwa dipahami dengan bentuk tertentu. Hasilnya, pemberitaan media pada sisi tertentu atau wawancara dengan orang tertentu. Semua elemen tersebut tidak hanya bagian dari teknik jurnalistik, tetapi menandakan bagaimana peristiwa dimaknai dan ditampilkan.

Zhongdang Pan dan Gerald M.Kosicky memandang analisis Framing ini dilihat sebagai wacana publik tentang suatu isu atau kebijakan dikonstruksikan dan dinegosiasikan. Teks berita dilihat terdiri dari berbagai simbol yang disusun lewat perangkat simbolik yang dipakai dan akan dikonstruksi dalam memori khalayak.

Prangkat framing dapat dibagi kedalam struktur besar. Pertama yaitu struktur sintaksis, struktur ini berhubungan dengan bagaimana wartawan menyusun 
peristiwa, pernyataan, opini, kutipan, pengamatan atas peristiwa kedalam bentuk susunan umum berita. Struktur ini dapat diamati dari bagian berita (Lead yang dipakai, latar, headline, kutipan yang diambil, dan sebagainya). Kedua yaitu struktur skrip, struktur ini berhubungan dengan bagaimana wartawan mengisahkan atau menceritakan peristiwa ke dalam bentuk berita. Struktur ini melihat bagaimana strategi cara bercerita atau bertutur dipakai oleh wartawan dalam mengemas peristiwa ke dalam bentuk berita.

Ketiga yaitu struktur tematik, struktur ini berhubungan dengan bagaimana wartawan mengungkapkan pandangannya atas peristiwa ke dalam proposisi, kalimat atau hubungan antarkalimat yang membentuk teks secara keseluruhan. Struktur ini akan melihat bagaimana pemahaman itu diwujudkan dalam bentuk yang lebih kecil. Keempat yaitu struktur retoris, struktur ini berhubungan dengan bagaimana wartawan menekankan arti tertentu ke dalam berita. Struktur ini akan melihat bagaimana wartawan memakai pilihan kata, idiom, grafik, dan gambar yang dipakai bukan hanya mendukung tulisan, melainkan juga menekankan arti tertentu kepada pembaca. Kecenderungan wartawan atau institusi media dalam memahami suatu peristiwa dapat diamati dari keempat struktur tersebut (Eriyanto, 2002).

\section{Metode Penelitian}

Penelitian ini menggunakan metode analisis framing model Zhong Pan dan Gerald M. Kosicky dengan metode pendekatan kualitatif yang tidak menggunakan perhitungan angka melainkan mengamati fenomena apa yang sedang terjadi. Pendekatan kualitatif adalah pendekatan yang di dalam usulan penelitian, proses, hipotesis, turun ke lapangan, analisis data dan kesimpulan data sampai dengan penulisannya mempergunakan aspek-aspek kecenderungan, non perhitungan numerik, situasional deskriptif, interview mendalam, analisis isi, bola salju, dan story. Menurut Sugiyono (2011) penelitian kualitatif adalah suatu metode penelitian yang berlandaskan pada filsafat postpositivisme, digunakan untuk meneliti pada kondisi objek yang alamiah dimana peneliti adalah sebagai instrumen kunci, pengambilan sampel sumber data dilakukan secara purposif, teknik pengumpulan dengan triangulasi, analisis bersifat induktif, dan hasil penelitian kualitatif lebih menekankan makna daripada generalisasi.

\section{Hasil dan Pembahasan}

Analisis framing ini dilakukan terhadap berita online yang dimuat oleh Tribunjogja.com dan Detik.com terkait kasus korupsi yang terjadi di dalam Menpora dengan data-data yang diperoleh dan dianalisis oleh peneliti menggunakan skema dan konsep model analisis Zhongdang Pan dan Gerald M. Kosicky, yang mengelompokkan ke dalam tiga dari empat sub kategori yaitu, sintaksis (bagaimana cara wartawan menyusun berita), skrip (bagaimana cara wartawan untuk menyusun fakta), tematik (bagaimana cara wartawan menuliskan fakta). Berikut hasil dari 
penelitian dari kedua berita online tersebut:

\subsection{Perbandingan Frame Media Online Detik.com dan TribunJogja.com}

Gambar 1. Foto laman berita Detik Sport

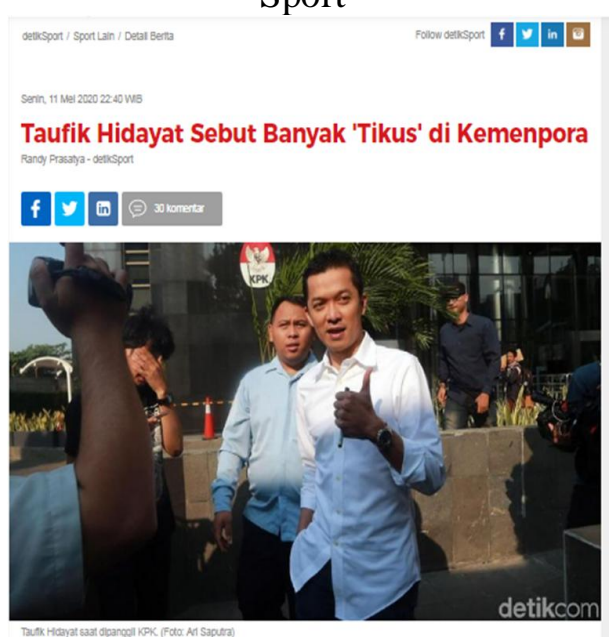

(Sumber: sport.detik.com)

Detik.com

Judul : "Taufik Hidayat Sebut Banyak 'Tikus' Di Kemenpora”

\section{Struktur Sintaksis}

Dilihat secara sintaksis bahwa berita ini menyampaikan tentang pengakuan Taufik Hidayat yang mengatakan bahwa banyak 'Tikus' di Kemenpora. Judul dan lead dalam berita ini sudah sangat menegaskan hal tersebut, sesuai dengan isi berita yang disampaikan dan sama dengan pernyataan Taufik Hidayat saat diundang dalam podcast milik Youtuber Deddy Corbuzier.

Dalam berita ini dipenuhi dengan pernyataan dan penjelasan Taufik Hidayat saat bincang-bincang santai dengan Deddy Corbuzier terkait pemanggilan namanya oleh KPK untuk menjadi saksi di kasus korupsi mantan Menpora Imam Nahrawi. Di Dalam berita tersebut dituliskan Taufik Hidayat dimintai kesaksiannya atas dugaan penerimaan suap Imam sebesar Rp 11,5 miliar dan gratifikasi Rp 8,648 miliar dari sejumlah pejabat Kemenpora dan Komite Olahraga Nasional Indonesia (KONI).

Taufik juga mengakui menjadi kurir penerima uang untuk Imam namun dia menegaskan melakukannya karena diperintah seseorang di Kemenpora tanpa ada kecurigaan. Didalam podcast Deddy Corbuzier tersebut Taufik memberikan pernyataan yang pedas bahwa banyak 'tikus' di Kemenpora sehingga siapapun menterinya juga sama saja dan mengatakan bahwa 'setengah gedung' di Kemenpora harus dibongkar.

\section{Struktur Skrip}

Berdasar struktur skrip, berita ini memiliki peletakan komposisi penyusunan unsur $5 \mathrm{~W}+1 \mathrm{H}$ sudah lengkap namun belum sempurna. Dalam hal ini yang menjadi pertanyaan saat pengakuan Taufik Hidayat yang disuruh oleh salah satu pejabat Kemenpora untuk menjadi kurir penerima uang suap mantan Menpora Imam Nahrawi harusnya menjelaskan dengan tegas dan lengkap siapa yang menyuruh Taufik untuk menjadi kurir pada kasus korupsi tersebut. Berita yang disampaikan di atas kurang terperinci karena tidak disebutkan siapa nama pejabat Kemenpora yang menyuruh Taufik dalam kasus korupsi tersebut

\section{Struktur Tematik}


Pada penyusunan berita di pengakuan Taufik Hidayat sebagai saksi kasus suap yang melibatkan mantan Menpora Imam Nahrawi. Meskipun judul berita tentang Taufik yang menyebutkan banyak tikus di Kemenpora, namun fokus isi berita disini adalah keseluruhan pengakuan Taufik Hidayat sebagai saksi di persidangan dan berbagai macam pengakuan lain yang disampaikan di dalam podcast youtuber Deddy Corbuzier

Gambar 2. Foto Laman Berita TribunJogja.com

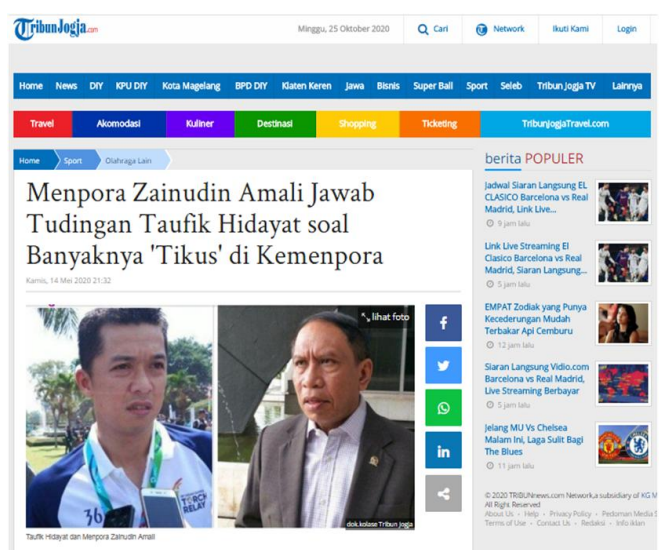

(Sumber: TribunJogja.com, 2020)

\section{TribunJogja.com}

Judul : "Menpora Zainudin Amali Jawab Tudingan Taufik Hidayat soal Banyaknya 'Tikus' di Kemenpora"

\section{Struktur Sintaksis}

Pada bagian struktur sintaksis, dalam pemberitaan mengenai Jawaban Menpora atas tudingan yang dilontarkan oleh Taufik Hidayat. Pada lead berita menceritakan bahwa Zainudin Amali memberikan tanggapan usai kementriannya dikritik oleh Taufik Hidayat. Di dalam berita tersebut informasi yang ada sangat informatif dan berkesinambungan. Pada isi pemberitaan tidak adanya keberpihakan, melainkan isi berita yang berimbang, terlihat dari beberapa kutipan tudingan yang dilontarkan Taufik mengenai adanya 'Tikus' di dalam Menpora, dan juga adanya beberapa kutipan tanggapan Zainudin Amali perwakilan Menpora yang menjawab atas tudingan tersebut.

\section{Struktur Skrip}

Pada bagian struktur skrip, berita ini sudah memiliki unsur $5 \mathrm{~W}+1 \mathrm{H}$ dengan rincian sebagai berikut: (What) Zainudin Amali menjawab tudingan Taufik Hidayat soal banyaknya 'Tikus' di Kemenpora; (When) Kamis, 14 Mei 2020; (Where) Taufik Hidayat diwawancarai di Gedung Sate, Bandung; (Who) Taufik Hidayat, Zainudin Amali; (Why) karena pengakuan sekaligus tudingan Taufik Hidayat mengenai adanya kasus korupsi di Kemenpora, Zainudin Amali menanggapi tudingan tersebut; (How) berawal dari Taufik Hidayat yang menjadi kurir kasus korupsi. Pada isi berita juga memiliki informasi yang urut tidak acak, sehingga tulisan berita tersebut lebih enak untuk dibaca oleh pembaca. Awalan berita yang berisi tentang beberapa ucapan yang dilontarkan Taufik Hidayat kepada Menpora, setelahnya adanya tanggapan dari Zainudin Amali yang juga berupa beberapa ucapan untuk menjawab tudingan tersebut. Di dalam pemberitaan tersebut juga memiliki kekurangan pada kurang rincinya siapa orang Menpora yang 
menyuruh Taufik Hidayat untuk menjadi kurir kasus korupsi, karena dalam berita tersebut hanya menyebutkan bahwa orang Menpora saja tidak adanya penjelasan yang detail siapa orang tersebut.

\section{Struktur Tematik}

Pada penyusunan berita tidak hanya berfokus kepada tanggapan Zainudin Amali atas tudingan Taufik Hidayat, tetapi juga adanya beberapa pernyataan atau tudingan yang dilontarkan oleh Taufik Hidayat. Tentunya hal itu terbilang selaras dengan Headline berita, karenanya pada isi berita tidak hanya berisi mengenai tanggapan dari Zainudin Amali, tetapi juga ada tudingan yang dilakukan oleh Taufik Hidayat.

\subsection{Framing Berita Dalam Kajian Teori Konstruksi Sosial Atas Realita (The Social Construction Of Reality Theory) \\ Jika diamati kembali, kedua \\ frame berita Detik.com dan TribunJogja.com sudah sejalan dengan Teori Konstruksi Realitas Sosial. Seperti menurut Heri (2020), setiap teks dan penulisan berita pada dasarnya dihasilkan lewat kesadaran, pengetahuan, prasangka atau pengetahuan tertentu atas suatu peristiwa. Bahasa merupakan salah satu pendukung penting dalam membentuk konstruksi realitas. Bahasa bukan hanya mampu mencerminkan realitas tetapi sekaligus menciptakan realitas (Hamad, 2001). Beranjak dari kajian diatas, maka Pemberitaan Taufik Hidayat terkait sebagai saksi dan pengakuan nya dalam kasus suap eks Menpora Imam Nahrawi dapat}

dipahami dengan menggunakan sebuah teori yaitu Teori Konstruksi Sosial Atas Realita (the Social Construction Of Reality Theory) yang dapat membedah atau menjelaskan makna dari sebuah realita berita tersebut. Berdasar tiga moment, diantaranya eksternalisasi, objektivasi, dan internalisasi.

\section{Eksternalisasi}

Dalam keterkaitannya dengan kajian eksternalisasi, peristiwa Taufik Hidayat dapat dipahami bahwa pendekatan dari segi sosiokultural mempunyai framing tersendiri. Dalam hal ini, sosiokultural berupa produk berita yang ditampilkan oleh media dengan sasaran masyarakat. Kedua media ini memiliki basis di Jakarta dan merupakan salah satu media online terbesar yang ada di Indonesia. Keunikan yang dimiliki oleh Tribunnews.com adalah memiliki Jaringan 28 koran daerah atau Tribun Network salah satunya yaitu TribunJogja.com yang berdomisili di provinsi Daerah Istimewa Yogyakarta. Media Tribunnews.com memang dikenal netral dalam memberitakan sesuatu atau peristiwa yang terjadi dan contoh kasusnya pada pemberitaan "Menpora Zainudin Amali Jawab Tudingan Taufik Hidayat". Media Detik.com akhir-akhir ini sedang mengalami masalah yang cukup serius yaitu penilaian masyarakat terhadap Detik.com sangat menurun drastis karena dituding kurang netral dan berita yang ditampilkan lebih provokatif.

\section{Internalisasi}


Media lebih menekankan identifikasi pada cara wartawan menulis berita yang tidak terlepas dari tata cara penulisan berita menurut lembaga atau organisasi (media) di dalam sebuah framing berita. Pada media Tribunjogja.com dan Detik.com, wartawan dalam menulis berita masih terfokus pada pengkajian dalam mengidentifikasi realita. Terdapat perbedaan yang signifikan dalam segi penulisan beritanya. Wartawan Detik.com penulisan dengan framingnya lebih dominan tentang pengakuan Taufik Hidayat dalam kasus Suap Eks Menpora, dalam pemberitaan ini banyak pengakuan Taufik saja yang diangkat untuk dijadikan berita oleh wartawan Detik.com. Wartawan dari media online JogjaTribunnews.com, menuliskan framingnya lebih berimbang dikarenakan di dalam penulisan awal dijelaskan beberapa pengakuan Taufik Hidayat, lalu dalam isi berita nya jawaban dari Menpora saat ini atas pengakuan Taufik Hidayat serta di akhir berita disimpulkan kronologi kasus suap yang beberapa periode terakhir selalu dilakukan oleh Menpora itu sendiri

\section{Objektivitas}

Dalam penelitian ini, peneliti sangat mengutamakan untuk bisa tetap bersikap netral dalam menelaah suatu realita berita yang ditampilkan oleh kedua media yang tentunya tidak memihak pada siapapun baik media Tribunjogja.com maupun Detik.com. Hal ini peneliti dituntut agar berita tersebut lebih objektif. Berdasarkan orientasi pemikiran peneliti pengakuan yang telah dilakukan oleh Taufik Hidayat baik fakta yang ada di persidangan maupun saat menjadi tamu undangan dalam podcast Deddy Corbuzier. Pengakuan tersebut merupakan informasi yang sangat penting untuk diterima masyarakat bahwa kementerian pemuda dan olahraga hingga saat ini belum sepenuhnya bersih dari praktik suap maupun korupsi. Hal yang juga sangat mengecewakan dalam pengakuan tersebut adalah olahraga di Indonesia hingga kini masih sering disusupi oleh kepentingan politik.

\section{Kesimpulan}

Berdasar analisis framing pada media online Tribunjogja.com dan Detik.com terhadap pemberitaan Taufik Hidayat kasus suap eks Menpora dengan konsep model analisis Zhongdang Pan dan Gerald M. Kosicky terdapat beberapa kesimpulan yaitu, Pertama, media online Tribunjogja.com memiliki isi berita yang tidak hanya mengedepankan pendapat salah satu pihak, terlihat dari isi berita tersebut tidak hanya berisi tentang pengakuan Taufik Hidayat saja tetapi juga adanya jawaban dari pihak Kemenpora. Hal ini membuat berita yang ditulis oleh Tribunjogja.com berita yang berimbang tidak memihak manapun. Berbeda dengan media online Detik.com memiliki isi berita yang lebih mengedepankan pendapat atau pengakuan dari Taufik Hidayat saja, sehingga membuat pembaca hanya melihat dari satu sisi saja. Hal ini berarti media online Detik.com terlihat memihak satu pihak dan tidak berimbang, yang seharusnya suatu berita memiliki isi yang berimbang atau netral tanpa memihak siapapun. Kedua, pada kedua media online yaitu 
Tribunjogja.com dan Detik.com terlihat sama memiliki kekurangan kelengkapan informasi seperti, kurang jelasnya pelaku yang menyuruh Taufik Hidayat untuk

\section{Daftar Pustaka}

\section{Buku:}

Berger, Peter L., Luckmann, Thomas. (1966). The Social Construction of Reality, The Treatise In The Sociology of Reality. New York, USA. : Penguin Books

Eriyanto. (2002). Analisis framing konstruksi, ideologi, dan politik media. Yogyakarta : LKIS.

Sobur, Alex. (2002). Analisis Teks Media: Suatu Pengantar untuk Analisa Wacana, Analisa Semiotika dan Analisa Framing , Bandung: Remaja Rosda Karya

Hamad, Ibnu. (2004). Konstruksi Realitas Politik dalam media massa. Jakarta : Yayasan Obor Indonesia.

Pavlik, Jhon, (2003). Converging Media: An Introduction to Mass Communication. Boston, Massachusetts: Allyn \& Bacon

\section{Jurnal:}

Buono, H., Maulina, P., \& Muzakkir, M. (2020). Analisis Framing Terhadap Pemberitaan Didiskualifikasinya Miftahul Jannah Dari Cabang Olahraga Judo. Source: Jurnal Ilmu Komunikasi, 5(2). https://doi.org/10.353 08/source.v5i2.1398

Aisyah, S., Pantow, J. T., \& Koagouw, F. V. I. (2015). Peran media online dalam meningkatkan prestasi belajar. $E$ Journal mengantarkan uang atau suap tersebut, walaupun yang kita tahu pelaku yang menyuruh Taufik Hidayat yaitu orang Kemenpora itu sendiri.

Acta Diurna Ilmu Komunikasi Fispol Universitas Sam Ratulangi, Vol IV(4).

Sinaga, Kumala C. S., and Belli Nasution. (2016) "Analisis Framing Pemberitaan Bom Sarinah di Kompas.com dan Merdeka.com." Jurnal Online Mahasiswa Fakultas Ilmu Sosial dan Ilmu Politik Universitas Riau, vol. 3, no. 2, Oct., pp. 1-12.

Lestari, P., Ramadhaniyanto, B., \& Wardyaningrum, D. (2018). Pemberitaan di media online untuk pengurangan risiko bencana gunung sinabung. Jurnal Kajian Komunikasi, 6(1), 106-120.

\section{Artikel Berita Online:}

Fatoni, Muhammad. (2020, Mei 14). Menpora Zainudin Amali Jawab Tudingan Taufik Hidayat Soal Banyaknya 'Tikus' di Kemenpora. TribunJogja.com.

https://jogja.tribunnews.com/2020/05/14 Imenpora-zainudin-amali-jawabtudingan-taufik-hidayat-soal-banyaknyatikus-di-kemenpora?page $=2$ (diakses pada 18 Juni 2020 pukul 10.00)

Prasatya, Sandi. (2020, Mei 11). Taufik Hidayat Sebut Banyak Tikus di Kemenpora. Detik.com. https://sport.detik.com/sport-lain/d5010944/taufik-hidayat-sebut-banyaktikus-di-kemenpora (diakses pada 18 Juni 2020 pukul 10.15)

MAP. (2019, Agustus 1) 3 Kisah Kontroversial Taufik Hidayaat. CNN Indonesia. https://www.cnnindonesia.com/olahraga 
/20190801150527-170-417441/3-kisahkontroversial-taufik-hidayat _ (diakses pada 26 September pukul 09.55)

Tirtana, Arief. (2020, April 16). 3 Rekor Fantastis Berikut Sukses Diukir Taufik Hidayat. Indosport.com https://www.indosport.com/raket/20200 416/3-rekor-fantastis-berikut-suksesdiukir-taufik-hidayat (diakses pada 26 September 2020 pukul 10.00)

Aditama Oryza. (2019, November 22). Sejarah Prestasi Badminton Indonesia di Sea Games dari Masa ke Masa. Tirto.id. https://tirto.id/sejarah-prestasi-

badminton-indonesia-di-sea-games-darimasa-ke-masa-eman (diakses pada 26 September 2020 pukul 10.10)

Hidayat, Anwar. (2012). Penelitian Kualitatif: Penjelasan Lengkap. Diperoleh dari (www.statistikian.com/2012/10/penelitia n-kualitatif.html )

Profil Taufik Hidayat. Diperoleh dari https://m.merdeka.com/taufik-

hidayat/profil/ (diakses pada 26

September pukul 09.50) 